\title{
Barriers in Online Learning Based on the First and Second Graders' Perspective
}

\author{
Ria Ambarsari ${ }^{1 凶}$, E. Kus Eddy Sartono', Winarni Jhon ${ }^{1}$ \\ Postgraduate School of Basic Education, Yogyakarta State University(1) \\ DOI: $10.31004 /$ obsesi.v6i3.1224
}

\begin{abstract}
Abstrak
Anak Sekolah Dasar (SD) kelas 1 dan 2 merupakan anak yang membutuhkan perhatian dan bimbingan yang lebih dari guru dan orang tua. Namun, anak SD di kelas 1 dan 2 menghadapi banyak tantangan dalam pembelajaran online. Oleh karena itu, kami bertujuan untuk mengeksplorasi tantangan yang dihadapi oleh 22 anak sekolah dasar di kelas 1 dan 2 (7-8 tahun) dalam pembelajaran online selama pandemi Covid-19 di 8 sekolah dasar di Palembang, Provinsi Sumatera Selatan, Indonesia. Penelitian ini merupakan penelitian kualitatif dengan jenis fenomenologi. Kami menemukan bahwa anak SD kelas 1 dan 2 menghadapi tantangan yang bervariasi baik dari anak itu sendiri (tantangan internal) maupun lingkungan seperti orang tua, guru dan lain-lain (tantangan eksternal). Semoga penelitian ini bermanfaat bagi para guru, kepala sekolah, warga sekolah lainnya dan pemerintah Indonesia dalam mengumpulkan informasi tentang tantangan yang terjadi dalam pembelajaran online selama pandemi Covid-19 dan solusinya.
\end{abstract}

Kata Kunci: tantangan; anak sd; kelas 1 dan 2; pembelajaran daring

\begin{abstract}
Primary school children in grade 1 and 2 are children who need more attention and guidance from teachers and parents. However, primary school children in grade 1 and 2 faced many challenges in online learning. Therefore, we aimed to explore challenges that 22 primary school children in grade 1 and 2 (7-8 years old) faced in online learning during Covid-19 pandemic in 8 primary schools in Palembang, South Sumatra Province, Indonesia. This research is a qualitative research with a type of phenomenology. We found that first and second grade primary school children faced varied challenges both from the children themselves (internal challenges) and the environment such as parents, teachers and others (external challenges). Hopefully, this research is useful for teachers, principals, other school members and government of Indonesia in gathering information about challenges that happened in online learning during Covid-19 pandemic and its solutions.
\end{abstract}

Keywords: challenges; primary school children; grade 1 and 2; online learning.

Copyright (c) 2021 Ria Ambarsari, et al.

$\triangle$ Corresponding author :

Email Address : riaambarsari.2019@student.uny.ac.id (Yogyakarta, Indonesia)

Received 24 March 2021, Accepted 27 April 2021, Published 13 September 2021 


\section{INTRODUCTION}

The implementation of online is important due to physical distance policy. Therefore, in order to continue learning process and monitor students development, online learning should be implemented. However, primary school children in grade 1 and 2 are struggling in online learning (Anggianita et al., 2020; Astini, 2020). Primary school children in grades 1 and 2 in Indonesia are 7-8 years old children who are still lacking in basic skills such as reading and good numeracy. Consequently, online learning can be less effective for primary school children in grades 1 and 2 because if this is done virtually, the students' ability to understand learning materials will not be optimal. In addition, there is difficulty for children to develop relationship and get to know their peers and teachers due to physical distancing policy (Wang et al., 2020). This also caused children to lose opportunities to learn since children are still used to face-to-face learning. Therefore, children need support, guide, motivation and children's need during online learning (Irwanto, 2020). The reason is because children's cognitive and mental abilities are not very well developed (Irwanto, 2020). Thus, they still depend on other parties such as teachers, parents and older sisters or brothers.

The impact of covid 19 hampers interaction and communication between teachers and students. Mufaziah \& Fauziah (2021) divided challenges in the implementation of online learning into 2 indicators namely internal \& external factors. This division is based on the cause of the challenges. Internal factors include interest, experience, competence, attitude, motivation, concentration, and mental \& physical condition. External factors include environment, peers, society, curriculum, media and infrastructure. Students often have limitations in the use of information and communication technology (Koedoes et al., 2020). This had showed that challenges in online learning is varied.

Most of previous research regarding online learning paid attentions on parents and grandparents such as the role of parents (e.g. Adhe et al., 2020; Rohita, 2021; Kurniati et al., 2021; Auliya \& Fauziah, 2021; Yulianingsih et al., 2021), role of grandparents (e.g. Sary, 2020; Pagarwati \& Rohman, 2021), and perception of parents (e.g. Handayani, 2021). Meanwhile, other researches about teachers mostly focused on strategies to prevent the infection on students (e.g. Wardhani et al., 2020; Anhusadar \& Islamiyah, 2021; Safitri \& Harun, 2021). This showed that there are still lack of researches that focused on challenges that students faced in online learning. Even though there were some researches about problems or challenges in online learning, most of them were conducted in undergraduate level (e.g. Moawad, 2020; Gomez et al., 2020; Perrotta \& Bohan, 2020; Nadolu, 2020; Mulenga \& Marbán, 2020), high school level (e.g. Basilaia \& Kvavadze, 2020; Mulyanti et al., 2020), and junior high school level (e.g. Clausen et al., 2020). This showed that there are still few researches who were conducted in early childhood and primary school level. This research gap analysis proved that there are limited information and studies that can provide an overview, information about challenges in online learning during Covid-19 pandemic especially for the first and second grade primary school children. Therefore, we aimed to identify the results of research regarding challenges that first and second grade primary school children faced in online learning during Covid-19 pandemic. Hopefully, this research is useful for teachers, principals, other school members and government of Indonesia in gathering information about challenges that happened in online learning during Covid-19 pandemic. This is really important since first and second grade primary school children (ranging from 7 until 8 years old children) is a period of transition from being a child who needs help (dependent) to a child who begins to be independent (independent), both physically and psychologically. Therefore, there should be guidance, and solutions to overcome challenges that happened in online learning.

\section{METHOD}

This research is a qualitative research with a type of phenomenology model. Qualitative method was chosen in order to get an in-depth approach in understanding and exploring social or human problems attributed to individuals or groups. Qualitative 
perspective raises deep fact to the surface rather than statistical data obtained from the simple questioning, by providing a more insightful and more comprehensive view in the analysis of the community and the individual. We also chose phenomenology model in order to gather examples, themes, and experiences that will help to describe and reveal a phenomenon. Thus, we could get in-depth and detailed understanding about a phenomenon. This type of research aims to reduce individual experiences from a certain phenomenon to a description (Creswell, 2007). Researchers explored the challenges of online learning based on first and second grade primary school children' perspective. This research was conducted from 15-29 March 2021.

The technique of selecting participants was purposive sampling with consideration of the research objectives. The participants in this study were 22 first and second grade students in primary schools in several sub-districts in Palembang City, South Sumatra Province such as Jakabaring, Plaju, Kertapati, Sukarami, Sako, Kalidoni, Kemuning, Ilir Barat I, Seberang Ulu I and Seberang Ulu II. The students were at the age of 7-8 years old. There were 12 female students and 10 male students. These students were chosen since they got permission from parents and teachers to be participants of this research. We only chose participants who agreed to be interviewed without any coercion. We also asked for permission from teachers and parents of students before conducting interview.

The data collection technique is in-depth interviews in order to reveal the phenomena and meaning of each research subject. Before the interviews, we developed questions for the interview independently. Then, we asked the opinions and suggestions from 2 experts, including one educational science professor and one lecturer from educational science faculty in Yogyakarta State University regarding the suitability of the questions. Lastly, we revised the questions of interview based on experts' suggestions. Interviews were conducted online WhatsApp video call to the students in order to prevent the spread of the COVID-19 virus. We conducted interview for 15-20 minute. Tabel 1 below is the characteristics of each respondent.

Table 1. Characteristics of Each Respondent

\begin{tabular}{lllll}
\hline Students & \multicolumn{1}{c}{ Grade } & \multicolumn{1}{c}{ Gender } & \multicolumn{1}{c}{$\begin{array}{c}\text { Address of } \\
\text { School }\end{array}$} & Age \\
& & & Jakabaring & 7 \\
S1 & First Grade & Female & Kalidoni & 7 \\
S2 & First Grade & Female & Ilir Barat I & 7 \\
S3 & First Grade & Male & Sako & 7 \\
S4 & First Grade & Male & Plaju & 7 \\
S5 & First Grade & Female & Ilir Barat I & 7 \\
S6 & First Grade & Male & Kertapati & 7 \\
S7 & First Grade & Male & Seberang Ulu I & 7 \\
S8 & First Grade & Female & Sukarami & 7 \\
S9 & First Grade & Female & Seberang Ulu II & 7 \\
S10 & First Grade & Female & Sako & 8 \\
S11 & Second Grade & Male & Kalidoni & 8 \\
S12 & Second Grade & Female & Kalidoni & 8 \\
S13 & Second Grade & Male & Kemuning & 8 \\
S14 & Second Grade & Female & Jakabaring & 8 \\
S15 & Second Grade & Male & Ilir Barat I & 8 \\
S16 & Second Grade & Female & Plaju & 8 \\
S17 & Second Grade & Female & Kertapati & 8 \\
S18 & Second Grade & Male & Kalidoni & 8 \\
S19 & Second Grade & Male & Sukarami & 8 \\
S20 & Second Grade & Female & Seberang Ulu I & 8 \\
S21 & Second Grade & Male & Seberang Ulu II & 8 \\
S22 & Second Grade & Female & & \\
\hline
\end{tabular}


Online interview method has several advantages, namely that it can cover a large geographical area, save energy and costs, and maintain the safety of the interviewer and interviewee (Novick, 2008). The topics of interviews focused on challenges that first and second grade students faced in online learning.

The data analysis technique in this study used the stages in the Bogdan \& Biklen (1982) model to determine inter-theme relations and gather a more detailed understanding. It begins with data reduction, followed by mapping data reduction into a theme, then identifying the interrelationships between themes, and ending with drawing conclusions on the findings. Figure 1 below showed data analysis technique.

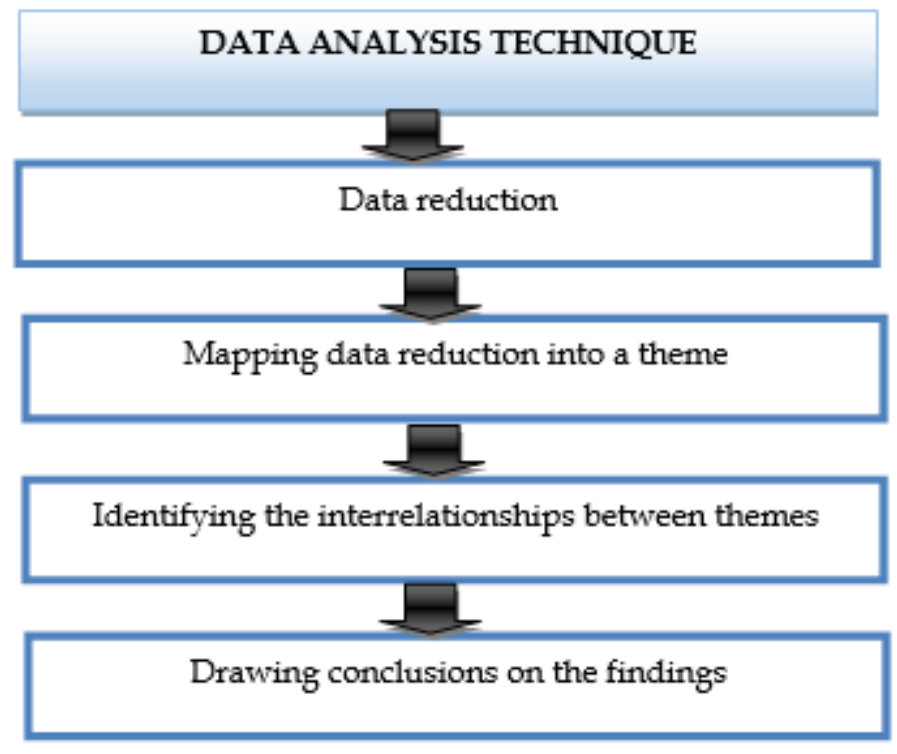

Figure 1. Data Analysis Technique

\section{RESULT AND DISCUSSION}

Primary school children in grade 1 and 2 are children who need more attention and guidance compared to primary school children in grades $3,4,5$, and 6 who on average can read and count (Astini, 2020). This is especially the case for primary school children in grade 1 since this is the time of transition to school (Erkan et al., 2018). They experience totally different conditions from home environment to school environment (Anggianita et al., 2020). Therefore, they are required to have readiness to face these changes and adjust to the school environment. Social, emotional readiness, intellectual, and language is needed by a child in transition to this school. However, primary school children in grade 1 and 2 faced many challenges in online learning. These challenges needed to be solved because this would influence children's development, learning, and stages of education for a long period of time (Erkan et al., 2018). We divided challenges that primary school children in grade 1 and 2 faced into 2 categories. They were external and internal challenges.

\section{External Challenges}

First, external challenges. These were challenges that come from the students' environment such as family, school and community. One of external challenges that students faced was lack of guidance and support from parents. Students claimed that their parents did not help them in studying. Students also claimed that this happened because their parents were busy. Therefore, they needed to wait for their parents. Meanwhile, other students needed to wait for their parents from their work. However, some of students stated that they did not want to study if their parents did not ask them to study. This issue need to be solved since online learning experience of each children greatly depends their environment such as resources and supports they got from their parents (Sun, 2011). However, due to Covid-19 
pandemic, parents became stressful in helping their children in online learning (Sun, 2011). Stressful parents pay little attention on children's needs, and learning (Fernandes et al., 2020; Spinelli et al., 2013). It is less likely for them to guide and monitor their children since they also have to deal with lots of issues (Gillis \& Roskam, 2019).

Based on the research conducted by Harahap et al., (2021) and Wijayanti \& Fauziah (2021), parents also had difficulties to manage their time. Parents found it difficult to guide and teach their children in online learning. This is in line with a survey conducted by Sari et al., (2021) towards 545 parents in Indonesia. This survey revealed that faced a challenge related to lack of time and poor time management skills. Parents were not able to accompany their children for a long time. They complained that they had many tasks and jobs that had to be done at the same time. Most of the parents had a job at the office such as lectures and teachers, private employee, civil servants and medical staff. These are type of jobs that focus on giving best services to the society. Some of those jobs even require parents to still work during Covid19 pandemic. They are doctors and medical staff. Some of them also work from home. Parents often felt tired (Sari et al., 2021; Mufaziah \& Fauziah, 2021; Pratiwi et al., 2020) and bored to help and guide their children in online learning during Covid-19 pandemic (Mufaziah \& Fauziah, 2021; Wijayanti \& Fauziah, 2021; Tabi'in, 2020; Khadijah \& Gusman, 2020; Lubis, 2018).

"My parents can not accompany me to study because they are often outside or not at home".

"My parents are so busy. My father work and my mother do household chores, babysit my sisters or brothers and others".

"My parents always work from morning until evening".

"When I want to study, I need to wait for my parents until they have done their work and go back from their work".

"My parents ask me to study with my sister or brother since they are busy".

"I don't like and want to study by myself. I will study if my parents ask me to study".

Table 2 showed challenges that primary school children in grade 1 and 2 faced in online learning.

Table 2. Challenges that Primary School Children in Grade 1 and 2 Faced in Online Learning

\begin{tabular}{|c|c|c|}
\hline Challenges & Theme & $\begin{array}{l}\text { Inter-theme } \\
\text { Relation }\end{array}$ \\
\hline No smartphone & External challenges & \multirow{15}{*}{$\begin{array}{l}\text { Students faced } \\
\text { varied challenges } \\
\text { both from the } \\
\text { students } \\
\text { themselves and } \\
\text { the environment } \\
\text { (parents, teachers } \\
\text { and others) }\end{array}$} \\
\hline Audio/ video issues & & \\
\hline Limited internet quota & & \\
\hline No guidance and support from parents & & \\
\hline Weak internet connection & & \\
\hline Disturbances from home & & \\
\hline Limited smartphone memory cards & & \\
\hline Unclear explanation from teachers & & \\
\hline Temperament parents & & \\
\hline Low battery & & \\
\hline $\begin{array}{l}\text { Still struggling in reading, writing and } \\
\text { counting }\end{array}$ & Internal challenges & \\
\hline Bad perception of online learning & & \\
\hline Loneliness and isolation & & \\
\hline Weariness (eyes, mind, back etc) & & \\
\hline Feeling afraid of parents and teachers & & \\
\hline
\end{tabular}

Other challenges that students faced related to parents were temperament parents. Students claimed that their parents would be angry especially when they got bad score, did 
mistakes and became lazy to do assignments. This issue needed to be solved because study result conducted by Phelps et al., (2014) and Erkan et al., (2018) showed that parents support can influence children's motivation and positive feelings about school. Erkan et al., (2018) stated that most of happy children were children who had parents that were interested on school-related children's activities.

"When I study, my parents always scold me almost every day".

"If I do mistakes and do not want to study, my parents will be angry".

"My parents will scold me if I get bad score from my teachers. If I cry, they will scold me even more".

Students also faced challenges related to unsupported home environment for online learning such as disturbance from siblings. Students also felt disturbed in studying. This caused them to lose their concentration to study. Ideally, learning environment should be comfortable and conducive for students (Singh, 2014). A conducive learning atmosphere will be created if it is supported by a comfortable and peaceful atmosphere around student learning area (Ahmad et al., 2015). A conducive learning environment is really important since it help students to achieve optimal learning outcomes.

"I have to fight for the smartphone with my brother or sister first in order for me to join online learning".

"If I want to study, my brothers or sisters will disturb me."

"My little brother ever tore my book. Thus, I cried".

"Sometimes, when I study, my mother asked me to do something".

"My siblings often ask to play and watch TV so I forgot to do my homework".

"I have many brothers or sisters. I could not concentrate well since there are so many noises at my home".

Aside from disturbance from inside the house, students also had to deal with noises that came from the surrounding environments. This caused lack of concentration and difficulties to study well for students. Locations of learning places that are too close to crowds such as markets, roadsides or factories tend to disrupt the concentration of students in learning (Arianti, 2017). Bad smell can also disturb the concentration of students in learning. For example, a place to study that is too close to a farm or rubber plantation area, will make the learning atmosphere less conducive and less comfortable (Arianti, 2017). Thus, the role of parents in providing safe and comfortable study environment for children at home is crucial (Wijayanti \& Fauziah, 2021).

"I live near a road. I had difficulties to make video for learning because there are so many noises from motorcycles and cars".

"My house is near a traditional market. Thus, my home environment is crowded. There were many people who passed by my house. I couldn't concentrate in studying well".

Aside from parents, students also faced challenges related to the teachers. Students often asked for help from their parents or siblings. The reason was because they often got confused due to unclear explanation about learning materials and assignments from the teachers. Online learning and physical distancing during Covid-19 pandemic hamper interaction and communication and interaction between teachers and students (Jhon et al., 2020). Lack of communication disrupts the learning process for students and affects childhood development as a whole (Agustin et al., 2021). Thus, the role of parent as a second teacher is crucial. Parents has important role to deliver messages from educators to children (Handayani, 2021). Parents must be able to translate the message and instruction given by the teacher so that parents are able to explain the message to children at home (Irwanto, 2020). In other words, parents should have good understanding about learning materials, children development and technological 
literacy or skills. Communication and collaboration between parents and teachers is crucial (Handayani, 2021). The word of collaboration is a term that has the meaning of taking part or having a role on certain activity (Irwanto, 2020). It means that both teachers and parents are involved in the learning process of children. Therefore, learning goals can be achieved successfully.

"I often don't understand what my teachers ask me to do".

"It is hard for me to understand learning materials since teachers just ask me to read the book".

"I usually ask my parents or siblings to explain learning material and assignment from the teachers".

"I am often confused about assignment given by the teachers. I always ask my parents or my siblings to help me".

In addition, students also faced challenges related to technical issues such as weak internet connection and limited internet quota. These caused difficulties for students to join virtual meeting, open and download electronic media, and join online learning on time. These were challenges that usually happened in online learning (Wardani \& Ayriza, 2021; Mufaziah \& Fauziah, 2021; Wijayanti \& Fauziah, 2021; Lubis, 2018). Access for internet is important in online learning. However, the need to increase internet connection for students become a big challenge especially those who live in rural and remote villages (Keengwe \& Bhargava, 2014). Without a good internet connection and enough internet quota, students cannot access learning platforms such as WhatsApp, Google Classroom, Zoom, and others well (Salsabila et al., 2020).

"I have weak internet connection to join virtual meeting. I really want to join zoom meeting but I have bad signal".

"If we study by using Zoom, I often got disconnected. I also couldn't open Youtube video"

"I need to wait for a long time to download videos or media given by teachers".

"I don't have enough internet quota. I need to wait for my parents to buy me quota. Even if I have, I only have night internet quota. Thus, I need to wait until night to open WhatsApp and give assignments to the teacher".

Students also faced challenges related to their smartphones such as lack of digital devices, audio and video issues, limited smartphone memory cards, and low battery. As a consequence, students could not participate in online learning. Even if they did, they could not enjoy online learning since they had errors in communicating and accessing instructional media. Other relevant researches also showed that there were teachers who did not implement online learning because not all students had laptops and Android phones to join online learning (Ayuni et al., 2021; Agustin et al., 2021; Muhdi et al., 2020). On the other hand, smartphone became an important device for students to be able to connect and communicate with teachers and school friends anywhere and anytime (Keengwe \& Bhargava, 2014). In order to access learning applications, the latest tools are needed to support online learning because online learning has started to use new technology to be able to support the learning process during the pandemic. The solution to overcome this challenge can be done by conducting home visit to students' houses on certain day in a week and routine daily reports from parents to teachers (Nahdi et al., 2021). Teachers in early childhood education conducted a home visit strategy to students' houses (Nirmala \& Annuar, 2021). Teachers in early childhood education in Central Sulawesi conducted home visit strategy twice a week (Nirmala \& Annuar, 2021). In the first visit, teachers encouraged play activities to groups of students. In the second visit, teachers monitored activities that have been carried out in the recent week. Home visit can be implemented in order to know about students's activities during the learning process (Foster et al., 2016; Lukie et al., 2014). 
"I only have one smartphone. I often can not participate in online learning since my smartphone was used by my father or mother or sister and brother".

"I ever lost my smartphone last month so I couldn't join online learning".

"I can not hear my teacher's voice clearly. My smartphone audio is error because I often had troubles in doing phone call or video calls".

"I could not download and save media given by my teachers because my smartphone memory card is already full".

"My phone's battery is draining so fast. My phone's battery is error. If I want to study, I need to charge my phone and wait until it is full. Then, I will join online learning".

\section{Internal Challenges}

Internal factors are factors that arise in students such as their preparedness in receiving lessons, physical conditions, and psychological conditions (Arianti, 2017). Internal factors usually are closely related to emotional problems, thoughts and behavior of students. First and second graders were still struggling in reading, writing and counting. Students claimed that they were bad in math. Others also claimed that they are still learning to read without spelling the words. Ideally, reading skills must be mastered by students particularly first and second graders because the process of teaching and learning activities is largely determined by their mastery of their initial reading skills (Pramesti, 2018). Students who were still struggling to read had difficulty capturing and understanding the information presented through various textbooks and supporting material books (Pramesti, 2018). As a result, their learning ability was slower than their peers who did not have difficulty reading.

"I could not read and write well. My mother would read and explain what my teachers were telling and asking in online learning".

"I could read but I could not read fast"

"I am still spelling the words".

"I am bad in math".

Students had bad perception about online learning. Students preferred face-to-face learning in the classroom than online learning because they could meet with their friends and teachers. Students also considered online learning as a boring learning since they were given a lot of assignments from their teachers. This is in line with research result conducted by Kurniasari et al., (2020) students felt that evaluation in the form of assigned assignments is burdensome since teachers gave a lot of assignments. On the other hand, teachers claimed that assignments given to the students is a process that is deliberately created by teachers to assess the learning process, not just to judge final performance only. This showed that different perceptions between students and teachers about the evaluation process. The difference in perception arises because of lack two-way communication between teachers and students. As a result, students are less active in responding instructions given by the teachers.

Kurniasari et al., (2020) suggested that teachers should not give a lot of assignments. However, type of questions should be more varied. In addition, there should be clear instruction about the assignments in order for students to understand well and to prevent confusion and misinterpretation.

In order to encourage positive perception on students about online learning, teachers should accommodate learning styles, flexibility and learning experiences of students (Oktavian \& Aldya, 2020).Support given by school to the teachers in designing and teaching online is also important to create positive online learning experience (Oktavian \& Aldya, 2020). Learning interactions should be fun, meaningful, inspire and help students develop ideas because students are at a time when they enjoy exploring the environment and actively seeking new experiences (Nurihsan \& Agustin, 2011). Therefore, it takes a lot of strategies that could accommodate students to exercise more interaction, increase their interest in learning. 
DOI: 10.31004/obsesi.v6i3.1224

Online learning will be very effective if it was integrated with the learning environment of students.

"I do not like online learning. I prefer studying in the classroom".

"I do not want online learning because I could not meet my teachers and friends".

"I want to study with my friends. I do not want online learning".

"I want to go to school. I do not like online learning".

"Online learning is not fun. I have to do a lot of assignment from teachers".

Based on the result of interview, we also found that students felt lonely since they could not meet their teachers and friends. There is difficulty for children to meet and get to know their peers and teachers due to physical distancing policy (Wang et al., 2020). Students prefer studying with their peers and teachers. This is in line with research result conducted by Kusuma \& Sutapa (2021) that during online learning at home and quarantine at home, students felt stressed and bored. They miss their friends and teachers. Thus, parents should give encouragement and reinforcement to their children.

"I miss my friends and teachers. I would like to meet them in the school".

"In online learning, I could not meet my friends and teachers. I hope I could go to school".

"I feel lonely because I need to study by myself without my friends".

"I wish we can go to the school because studying at home is quite and I feel lonely".

"I do not want online learning. I want to study at school. I am happy if I can learn with my friends

Other challenges that students faced was weariness. Students claimed that they got issues such as eye fatigue, blurry vision, and dizziness because they need to hold and see their smartphone for a long time. This is in line with research result conducted by Pawicara \& Conilie (2020) that during online learning, students suffered health problems such as dizziness and eye pain due to frequent and prolonged staring at cellphone screens and laptop or computer. This research also revealed that some students need to help their parents while following online learning and doing assignments. Thus, it triggers physical complaints felt by students. Other relevant researches also showed that online learning caused fatigue, eye strain, depression and feeling of isolation (e.g. Kapasia et al., 2020; Wang et al., 2020; Atmojo \& Nugroho, 2020).

"I got eye fatigue after I study".

"My head became dizzy".

"I got blurry vision".

Students were also afraid of their parents and teachers. Students claimed that their parents were so furious if students did not understand and study well. As a result, students were afraid to ask questions and even to study. In addition, they were also afraid to ask, talk and chat with their teachers. Ideally, learning process should be centered on students in order for them to be active participants in their learning environment. There are at least three elements that need to be considered in an effective learning communication (Agustin et al, 2021). They are communicator, messages, and communication partners. In learning activities, these three elements become important elements. Teachers should not be the only one who are active in online learning. Teachers should encourage their students to actively participate, ask and answer questions in online learning in order to create effective learning communication.

In addition, lockdown policy from government cause stress on parents (Sun, 2011; Pratiwi, 2021; Pratiwi et al., 2020; Dina, 2020). As a result, parents became more impatient and sensitive. This could cause bad impact on emotional condition of children (Neece et al., 2012) and hamper relationship between parents and children (Neece et al., 2012; Oxford \& Lee, 2011). Based on a study conducted by Jiao et al., (2020), children were easily scared, irritable, clinging, 
and inattentive due to lockdown policy. Thus, both teachers and parents need to be patient and understanding in helping and teaching their children at home.

"I am afraid to ask my parents. If I do not understand about questions given by teachers, I will not ask my parents".

"I am afraid to ask my teachers because she/ he would not reply my questions".

"I am afraid to ask my parents because I am afraid they will be angry to me".

"I do not want to ask my teachers because I am afraid with her/him".

In order to minimalize these challenges, government should provide guidelines, training, online workshop, and online meeting about online learning (Cicco, 2013). Guidelines about online learning were really important. The reason was because learning activities demanding interactive, creative, meaningful and fun learning (Agustin et al., 2021). Therefore, teachers can have better understanding and skills to conduct online learning for students. Good understanding and skills about online learning were really important especially for teachers. The reason was because learning activities demand interactive, creative, meaningful and fun learning (Agustin et al., 2021). Regarding lack of internet quota, the government of Indonesia and other stakeholders has provided internet quota subsidies for students, teachers, students and lecturers for four months. However, this subsidy need to distributed equally to all areas in Indonesia in order to ensure that students get the same facility and opportunity to study.

Not only government, teachers' role is also crucial. Teachers must have good knowledge and skills in implementing suitable learning methods in order to create interesting, fun, and meaningful learning (Agustin et al., 2021). Teachers should also be creative. Teachers' creativity is related to or has an influence on the learning outcomes of students (Herawati et al., 2019). Teacher creativity can encourage student motivation because creative teachers are able to develop their abilities and create new ideas. Teacher creativity does not only affect student learning motivation, but can directly affect student learning outcomes. The creativity of the teacher, of course, must be nurtured and developed by not only requiring the personal effort of the teacher, but also support from other parties such as parents and principal. Efforts to develop creativity can take the form of coaching, training, supervision, or encouragement (giving awards). Thus, they need to continuously develop and increase their knowledge and skills by searching in a variety of sources, sharing with other teachers, and joining lots of training and online workshop. Discussion between teachers and other parties such as principals, lectures, other teachers, and parents is really important (Perrotta \& Bohan, 2020). During the preparation of online learning, teachers need to prepare media, learning material, methods, learning sources. Not only physical preparation, teachers should have mental preparation especially in online learning. Mental preparation are related to the preparation of strategies, approach, technical learning, thoughts, and anxiety, stress \& fears control (Abd-ElKader et al., 2016). Teachers need to have confidence, motivation, and creativity. During evaluating activity, teachers need to be competent in selecting type of assessment for students (Muhdi \& Nurkolis, 2021; Pudyastuti \& Budiningsih, 2021) and achieving learning goals (Agustin et al., 2021; Pudyastuti \& Budiningsih, 2021). The assessment of learning in early childhood should focus on observation and interaction between the students and the teacher so that the teacher can find out and develop the abilities possessed by the students.

Another party that needed to be involved in to achieve successful online learning is parents. The role of parents during this online learning is also important (Nahdi et al., 2021). Parents can become teachers at home who can help students in online learning (Nahdi et al., 2021). According to Bustan et al., (2016), parents are the core of students's development because parents have more interaction and communication with students compared to teachers. They are also able to monitor students' activities directly during online learning process and playing at home (Solari et al., 2014). Parents can participate in online learning in 
terms of reporting students's activities to classroom teachers. Therefore, all students's activities can be reported and monitored by teachers.

This research is expected to give information about challenges that first and second grade primary school children face in online learning during Covid-19 pandemic. Therefore, there should be guidance, and solutions to overcome challenges that happened in online learning.

The limitation of this study was the limit of sample size. We only identify the need analysis from 8 primary schools in in Palembang. Therefore, we propose research about challenges in online learning in other provinces or regions of Indonesia such as Java, Kalimantan, Sulawesi and others.

\section{CONCLUSIONS}

Based on the result of interviews, we concluded that first and second grade primary school children faced varied challenges. The role of government, teachers and parents are crucial to solve these challenges. Government should provide guidelines, training, online workshop, internet quota and supporting infrastructure for online learning. Teachers must have good knowledge and skills about online learning. Teachers need to have good communication and collaboration with parents. On the other hand, parents should provide guidance and attention for their children at home.

\section{ACKNOWLEDGEMENT}

I would like to thank to my all of my lectures in Yogyakarta State University who had taught me a lot about writing a good article in journal.

\section{REFERENCES}

Abd-El-Kader, B., Fatiha, B., \& Khalida, B. (2016). Why Mental Preparation Is So Important On Directing Of Athletic Performance? European Journal of Physical Education and Sport Science, 2(5), 140-152. https:// doi.org/10.5281/zenodo.240931

Adhe, K. R., Maulidiya, R., Al Ardha, M. A., Saroinsong, W. P., \& Widayati, S. (2020). Learning During the Covid-19 Pandemic: Correlation Between Income Levels And Parental Roles. Jurnal Obsesi: Jurnal Pendidikan Anak Usia Dini, 5(1), 293-302. https://doi.org/10.31004/obsesi.v5i1.554

Agustin, M., Puspita, R. D., Nurinten, D., \& Nafiqoh, H. (2021). Tipikal Kendala Guru PAUD dalam Mengajar pada Masa Pandemi Covid 19 dan Implikasinya. Jurnal Obsesi : Jurnal Pendidikan Anak Usia Dini, 5(1), 334-345. https://doi.org/10.31004/obsesi.v5i1.598

Ahmad, S. S., Shaari, M. F., Hashim, R., \& Kariminia, S. (2015). Conducive Attributes of Physical Learning Environment at Preschool Level for Slow Learners. Procedia - Social and Behavioral Sciences, 201, 110-120. https://doi.org/10.1016/i.sbspro.2015.08.138

Anggianita, S., Yusnira, Y., \& Rizal, M. S. (2020). Persepsi Guru terhadap Pembelajaran Daring di Sekolah Dasar Negeri 013 Kumantan. Journal of Education Research, 1(2), 177-182. https://doi.org/10.37985/joe.v1i2.18

Anhusadar, L. O., \& Islamiyah. (2021). Penerapan Perilaku Hidup Bersih dan Sehat Anak Usia Dini di Tengah Pandemi Covid 19. Jurnal Obsesi : Jurnal Pendidikan Anak Usia Dini, 5(1), 463475. https://doi.org/10.31004/obsesi.v5i1.555

Arianti. (2017). Urgensi lingkungan belajar yang kondusif dalam mendorong siswa belajar aktif. $\begin{array}{llll}\text { Didaktika Jurnal Kependidikan, 11(1), 41-62. } & \text {. }\end{array}$ https://doi.org/10.30863/didaktika.v11i1.161

Astini, N. K. S. (2020). Pemanfaatan Teknologi Informasi dalam Pembelajaran Tingkat Sekolah Dasar pada Masa Pandemi Covid-19. Jurnal Lembaga Penjaminan Mutu STKIP Agama Hindu Amlapura, 11(2), 13-25. https:/ / doi.org/10.47730/jurnallampuhyang.v11i2.194

Atmojo, A. E. P., \& Nugroho, A. (2020). EFL Classes Must Go Online! Teaching Activities and Challenges during COVID-19 Pandemic in Indonesia. Register Journal, 13(1), 49-76. https://doi.org/10.18326/rgt.v13i1.49-76 
Auliya, A. F. S., \& Fauziah, P. Y. (2021). Advices for Involving Parents in Children ' s Learning Activities from School to Home. Jurnal Obsesi : Jurnal Pendidikan Anak Usia Dini, 5(2), 1073-1082. https://doi.org/10.31004/obsesi.v5i2.621

Ayuni, D., Marini, T., Fauziddin, M., \& Pahrul, Y. (2021). Kesiapan Guru TK Menghadapi Pembelajaran Daring Masa Pandemi Covid-19. Jurnal Obsesi : Jurnal Pendidikan Anak Usia Dini, 5(1), 414-421. https://doi.org/10.31004/obsesi.v5i1.579

Basilaia, G., \& Kvavadze, D. (2020). Transition to Online Education in Schools during a SARS-CoV2 Coronavirus Transition to Online Education in Schools during a SARS-CoV-2 Coronavirus ( COVID-19 ) Pandemic in Georgia. Pedagogical Research, 5(4), 1-9. https://doi.org/10.29333/pr/7937

Bogdan, R. C., \& Biklen, S. K. (1982). Qualitative Research for Education: An Introduction to Theory and Methods. Third Edition. Boston: Allyn and Bacon.

Bustan, R., Nurfadilah, \& Fitria, N. (2016). Pelatihan Optimalisai Tumbuh Kembang Anak pada Orangtua Anak Usia Dini. JURNAL Al-AZHAR INDONESIA SERI HUMANIORA, 3(3), 274-282. https:// doi.org/10.36722/sh.v3i3.214

Cicco, G. (2013). Faculty Development on Online Instructional Methods: A Protocol For Counselor Educators. Journal of Educational Technology, 10(2), 1-7. https://doi.org/10.26634/jet.10.2.2408

Clausen, J. M., Bunte, B. L., \& Robertson, E. T. (2020). Professional Development to Improve Communication and Reduce the Homework Gap in Grades 7-12 During COVID-19 Transition to Remote Learning. Jl. of Technology and Teacher Education, 28(2), 443-451.

Creswell, J. W. (2007). Qualitative Inquiry and Five, Research Design_Choosing among States, Approaches. 2nd edition. United State of America: Sage Publication.

Dina, L. N. A. B. (2020). Respon Orang Tua Terhadap Pembelajaran Daring pada Masa Pandemi Covid-19. THUFULI: Jurnal Ilmiah Pendidikan Islam Anak Usia Dini, 2(1), 2020. https://doi.org/10.33474/thufuli.v2i1.6925

Erkan, N. S., Tarman, I., Sanli, Z. S., Kosan, Y., \& Omruuzun, I. (2018). First Grade Students' Perceptions of Their Preschool and Elementary School Experience. International Journal of Progressive Education, 14(5), 1-13. https:// doi.org/10.29329/ijpe.2018.157.1

Fernandes, D. V., Canavarro, M. C., \& Moreira, H. (2020). The Mediating Role of Parenting Stress in the Relationship Between Anxious and Depressive Symptomatology, Mothers' Perception of Infant Temperament, and Mindful Parenting During the Postpartum Period. Mindfulness. https:// doi.org/10.1007/s12671-020-01327-4

Foster, T. D., Froyen, L. C., Skibbe, L. E., Bowles, R. P., \& Decker, K. B. (2016). Fathers' and mothers' home learning environments and children's early academic outcomes. Reading and Writing, 29(9), 1845-1863. https:// doi.org/10.1007/s11145-016-9655-7

Gillis, A., \& Roskam, I. (2019). Daily Exhaustion and Support in Parenting: Impact on the Quality of the Parent-Child Relationship. Journal of Child and Family Studies, 28(7), 2007-2016. https://doi.org/10.1007/s10826-019-01428-2

Gomez, E., Azadi, J., \& Magid, D. (2020). Innovation Born in Isolation: Rapid Transformation of an In-Person Medical Student Radiology Elective to a Remote Learning Experience During the COVID-19 Pandemic. Academic Radiology, 27(9), 1285-1290. https://doi.org/10.1016/j.acra.2020.06.001

Handayani, O. D. (2021). Persepsi Orangtua terhadap Pelaksanaan Belajar dari Rumah pada Pendidikan Anak Usia Dini. Jurnal Obsesi: Jurnal Pendidikan Anak Usia Dini, 5(2), 17541763. https://doi.org/10.31004/obsesi.v5i2.975

Harahap, S. A., Dimyati, \& Purwanta, E. (2021). Problematika Pembelajaran Daring dan Luring Anak Usia Dini bagi Guru dan Orang tua di Masa Pandemi. Jurnal Obsesi: Jurnal Pendidikan Anak Usia Dini, 5(2), 1825-1836. https://doi.org/10.31004/obsesi.v5i2.1013

Herawati, R., Mujahidin, E., \& Hamat, A. Al. (2019). Hubungan Motivasi Dan Kreativitas Guru Dalam Mengajar Dengan Hasil Belajar Mata Pelajaran PAI di Madrasah Aliyah Negeri 4 BOGOR. Jurnal Teknologi Pendidikan, 8(2), 235-246. https://doi.org/10.32832/tek.pend.v8i2.1507 
Irwanto, M. S. H. (2020). Implementasi Kolaborasi Orang Tua dan Guru Dalam Pelaksanaan Pembelajaran Daring pada PAUD. JIEES: Journal of Islamic Education at Elementary School, 1(1), 17-24. https://doi.org/10.47400/jiees.v1i1.8

Jhon, W., Mustadi, A., \& Zubaidah, E. (2020). Online Learning during Covid-19 Pandemic in Developing Countries: Does it run well ? Jurnal Pendidikan Progresif, 10(3), 440-454. https:// doi.org/10.23960/jpp.v10.i3.202006

Jiao, W. Y., Wang, L. N., Liu, J., Fang, S. F., \& Jiao, F. Y. (2020). Behavioral and Emotional Disorders in Children during the COVID-19 Epidemic. The Journal of Pediatrics, 221, 264-266. https://doi.org/10.1016/j.jpeds.2020.03.013

Kapasia, N., Paul, P., Roy, A., Saha, J., Zaveri, A., Mallick, R., Barman, B., Das, P., \& Chouhan, P. (2020). Impact of lockdown on learning status of undergraduate and postgraduate students during COVID-19 pandemic in West Bengal, India. Children and Youth Services Review, 116, 105194. https://doi.org/10.1016/j.childyouth.2020.105194

Keengwe, J., \& Bhargava, M. (2014). Mobile learning and integration of mobile technologies in education. Education and Information Technologies, 19(4), 737-746. https://doi.org/10.1007/s10639-013-9250-3

Khadijah, \& Gusman, M. (2020). Pola Kerja Sama Guru dan Orang Tua Mengelola Bermain AUD Selama Masa Pandemi Covid-19. Jurnal Kumara Cendekia, 8(2), 154-171. https://doi.org/10.20961/kc.v8i2.41871

Koedoes, Y. A., Abubakar, S. R., Hijriani, \& Nur, M. N. A. (2020). Solusi Pembelajaran Anak Usia Dini pada Masa Pandemi Covid-19. Jurnal Pengabdian Masyarakat Ilmu Terapan, 2(2), 8792.

Kurniasari, A., Pribowo, F. S. P., \& Putra, D. A. (2020). Analisis Efektivitas Pelaksanaan Belajar Dari Rumah (Bdr) Selama Pandemi Covid-19. Jurnal Review Pendidikan Dasar: Jurnal Kajian Pendidikan Dan Hasil Penelitian, 6(3), 1-8. https://doi.org/10.26740/jrpd.v6n3.p246-253

Kurniati, E., Alfaeni, D. K. N., \& Andriani, F. (2021). Analisis Peran Orang Tua dalam Mendampingi Anak di Masa Pandemi Covid-19. Jurnal Obsesi : Jurnal Pendidikan Anak Usia Dini, 5(1), 241-256. https://doi.org/10.31004/obsesi.v5i1.541

Kusuma, W. S., \& Sutapa, P. (2021). Dampak pembelajaran daring terhadap perilaku sosial emosional anak. Jurnal Obsesi: Jurnal Pendidikan Anak Usia Dini, 5(2), 1635-1643. https://doi.org/10.31004/obsesi.v5i2.940

Lubis, R. (2018). The Progress of Students Reading Comprehension through Wordless Picture Books. Advances in Language and Literary Studies, 9(1), 48-52. https://doi.org/10.7575/aiac.alls.v.9n.1p.48

Lukie, I. K., Skwarchuk, S. L., LeFevre, J. A., \& Sowinski, C. (2014). The Role of Child Interests and Collaborative Parent-Child Interactions in Fostering Numeracy and Literacy Development in Canadian Homes. Early Childhood Education Journal, 42(4), 251-259. https://doi.org/10.1007/s10643-013-0604-7

Moawad, R. A. (2020). Online Learning during the COVID- 19 Pandemic and Academic Stress in University Students. Revista Romaneasca Pentru Educatie Multidimensionala, 12(1Sup2), 100-107. https://doi.org/10.18662/rrem/12.1sup2/252

Mufaziah, E., \& Fauziah, P. Y. (2021). Kendala Orang Tua dalam Mendidik Anak Usia Dini pada Saat Pandemi Covid 19. Jurnal Obsesi : Jurnal Pendidikan Anak Usia Dini, 5(2), 1045-1051. https://doi.org/10.31004/obsesi.v5i2.746

Muhdi, \& Nurkolis. (2021). Keefektivan Kebijakan E-Learning berbasis Sosial Media pada PAUD di Masa Pandemi Covid-19. Jurnal Obsesi : Jurnal Pendidikan Anak Usia Dini, 5(1), 212228. https://doi.org/10.31004/obsesi.v5i1.535

Muhdi, Nurkolis, \& Yuliejantiningsih, Y. (2020). The Implementation of Online Learning in Early Childhood Education During the Covid-19 Pandemic. JPUD - Jurnal Pendidikan Usia Dini, 14(2), 247-261. https:// doi.org/10.21009/JPUD.142.04

Mulenga, E. M., \& Marbán, J. M. (2020). Prospective teachers' online learning mathematics activities in the age of COVID-19: A cluster analysis approach. Eurasia Journal of Mathematics, Science and Technology Education, 16(9). https://doi.org/10.29333/ejmste/8345 
Mulyanti, B., Purnama, W., \& Pawinanto, R. E. (2020). Distance Learning in Vocational High Schools during the COVID-19 Pandemic in West Java Province, Indonesia. Indonesian Journal of Science \& Technology, 5(2), 271-282. https:// doi.org/10.17509/ijost.v5i2.24640

Nadolu, B. (2020). Perspectives of Romanian Students about Life in Social Isolation. Journal of Research in Higher Education, 4(1), 32-43. https:// doi.org/10.24193/JRHE.2020.1.3

Nahdi, K., Ramdhani, S., Yuliatin, R. R., \& Hadi, Y. A. (2021). Implementasi Pembelajaran pada Masa Lockdown bagi Lembaga PAUD di Kabupaten Lombok Timur. Jurnal Obsesi : Jurnal Pendidikan Anak Usia Dini, 5(1), 177-186. https://doi.org/10.31004/obsesi.v5i1.529

Neece, C. L., Green, S. A., \& Baker, B. L. (2012). Parenting Stress and Child Behavior Problems : A Transactional Relationship Across Time. American Journal on Intellectual and Developmental Disabilities, 117(1), 48-66. https:// doi.org/10.1352/1944-7558-117.1.48

Nirmala, B., \& Annuar, H. (2021). Home Visit: Strategi PAUD dari Rumah bagi Guru di Daerah $3 T$ pada Masa Pandemi Covid-19. Jurnal Obsesi : Jurnal Pendidikan Anak Usia Dini, 5(2), 1052-1062. https://doi.org/10.31004/obsesi.v5i2.716

Novick, G. (2008). Is there a bias against telephone interviews in qualitative research? Research in Nursing and Health, 31(4), 391-398. https://doi.org/10.1002/nur.20259

Nurihsan, A. J., \& Agustin, M. (2011). Dinamika perkembangan anak dan remaja: Tinjauan psikologi, pendidikan, dan bimbingan. Bandung: Refika Aditama.

Oktavian, R., \& Aldya, R. F. (2020). Efektivitas Pembelajaran Daring Terintegrasi di Era Pendidikan 4.0. Didaktis: Jurnal Pendidikan Dan Ilmu Pengetahuan, 20(2), 129-135. https://doi.org/10.30651/didaktis.v20i2.4763

Oxford, M. L., \& Lee, J. O. (2011). The effect of family processes on school achievement as moderated by socioeconomic context is. Journal of School Psychology, 49(5), 597-612. https://doi.org/10.1016/j.jsp.2011.06.001

Pagarwati, L. D. A., \& Rohman, A. (2021). Grandparenting Membentuk Karakter Anak Usia Dini di Masa Pandemi Covid-19. Jurnal Obsesi : Jurnal Pendidikan Anak Usia Dini, 5(2), 12291239. https:// doi.org/10.31004/obsesi.v5i2.831

Pawicara, R., \& Conilie, M. (2020). Analisis Pembelajaran Daring Terhadap Kejenuhan Belajar Mahasiswa Tadris Biologi Iain Jember di Tengah Pandemi Covid-19. ALVEOLI: Jurnal Pendidikan Biologi, 1(1), 29-38. https://doi.org/10.35719/alveoli.v1i1.7

Perrotta, K., \& Bohan, C. H. (2020). A reflective study of online faculty teaching experiences in higher education. Journal of Effective Teaching in Higher Education, 3(1), 50-66. https://doi.org/10.36021/jethe.v3i1.9

Phelps, R., Graham, A., Tuyet, N. H. T., \& Geeves, R. (2014). Exploring Vietnamese children's experiences of, and views on, learning at primary school in rural and remote communities. International Journal of Educational Development, 36, 33-43. https://doi.org/10.1016/j.ijedudev.2013.12.004

Pramesti, F. (2018). Analisis Faktor-Faktor Penghambat Membaca Permulaan pada Siswa Kelas 1 SD. Jurnal Ilmiah Sekolah Dasar, 2(3), 283-289. https:// doi.org/10.23887/jisd.v2i3.16144

Pratiwi, H. (2021). Screen Time dalam Perilaku Pengasuhan Gererasi Alpha pada Masa Tanggap Darurat Covid-19. Jurnal Obsesi: Jurnal Pendidikan Anak Usia Dini, 5(1), 265-280. https://doi.org/10.31004/obsesi.v5i1.544

Pratiwi, H., Yarliani, I., Ismail, M., Haida, R. N., \& Asmayanti, N. (2020). Assessing the Toxic Levels in Parenting Behavior and Coping Strategies Implemented During the COVID-19 Pandemic. Jurnal Pendidikan Usia Dini, 14(2), 231-246. https://doi.org/10.21009/JPUD.142.03

Pudyastuti, A. T., \& Budiningsih, C. A. (2021). Efektivitas Pembelajaran E-Learning pada Guru PAUD Selama Pandemic Covid-19. Jurnal Obsesi: Jurnal Pendidikan Anak Usia Dini, 5(2), 1667-1675. https://doi.org/10.31004/obsesi.v5i2.873

Rohita. (2021). Pengenalan Covid-19 pada Anak Usia Prasekolah: Analisis pada Pelaksanaan Peran Orangtua di Rumah. Jurnal Obsesi : Jurnal Pendidikan Anak Usia Dini, 5(1), 315-326. https://doi.org/10.31004/obsesi.v5i1.528

Safitri, H. I., \& Harun. (2021). Membiasakan Pola Hidup Sehat dan Bersih pada Anak Usia Dini Selama Pandemi Covid-19. Jurnal Obsesi : Jurnal Pendidikan Anak Usia Dini, 5(1), 385-394. https://doi.org/10.31004/obsesi.v5i1.542 
DOI: 10.31004/obsesi.v6i3.1224

Salsabila, U. H., Lestari, W. M., Habibah, R., Andaresta, O., \& Yulianingsih, D. (2020). Pemanfaatan Teknologi Media Pembelajaran di Masa Pandemi Covid-19. Jurnal Pendidikan Dasar, 2(2), 1-13. https:// doi.org/10.30742/tpd.v2i2.1070

Sari, D. A., Mutmainah, R. N., Yulianingsih, I., Tarihoran, T. A., \& Bahfen, M. (2021). Kesiapan Ibu Bermain Bersama Anak Selama Pandemi Covid-19, "Dirumah Saja." Jurnal Obsesi : Jurnal Pendidikan Anak Usia Dini, 5(1), 476-489. https://doi.org/10.31004/obsesi.v5i1.548

Sary, Y. N. E. (2020). Cara Asuh Nenek pada Anak Usia Dini di Masa Pandemi Covid-19. Jurnal Obsesi : Jurnal Pendidikan Anak Usia Dini, 5(1), 327-333. https://doi.org/10.31004/obsesi.v5i1.585

Singh, A. (2014). Conducive Classroom Environment in Schools. International Journal of Science and Research (IJSR), 3(1), 387-392.

Solari, E. J., Aceves, T. C., Higareda, I., Tutor, C. R., Filippini, A. L., Gerber, M. M., \& Leafstedt, J. (2014). Longitudinal prediction of 1st and 2nd grade english oral reading fluency in english language learners: which early reading and language skills are better predictors? Psychology in the Schools, 51(2), 126-142. https:// doi.org/10.1002/ pits.21743

Spinelli, M., Poehlmann, J., \& Bolt, D. (2013). Predictors of parenting stress trajectories in premature infant-mother dyads. Journal of Family Psychology, 27(6), 873-883. https://doi.org/10.1037/a0034652

Sun, S. Y. H. (2011). Online language teaching: The pedagogical challenges. Knowledge Management and E-Learning: An International Journal, 3(3), 428-447. https:// doi.org/10.34105/j.kmel.2011.03.030

Tabi'in, A. (2020). Problematika Stay At Home Pada Anak Usia Dini Di Tengah Pandemi Covid 19. Jurnal Golden Age, 04(1), 190-200.

Wang, G., Zhang, Y., Zhao, J., Zhang, J., \& Jiang, F. (2020). Mitigate the effects of home confinement on children during the COVID-19 outbreak. The Lancet, 395(10228), 945-947. https://doi.org/10.1016/S0140-6736(20)30547-X

Wardani, A., \& Ayriza, Y. (2021). Analisis Kendala Orang Tua dalam Mendampingi Anak Belajar di Rumah Pada Masa Pandemi Covid-19. Jurnal Obsesi : Jurnal Pendidikan Anak Usia Dini, 5(1), 772-782. https://doi.org/10.31004/obsesi.v5i1.705

Wardhani, D. K., Susilorini, M. R., Angghita, L. J., \& Ismail, A. (2020). Edukasi Pencegahan Penularan COVID-19 Pada Anak Usia Dini Melalui Media Pembelajaran Audio Visual. JURNAL ABDIDAS, 1(3), 131-136. https:// doi.org/10.31004/abdidas.v1i3.33

Wijayanti, R. M., \& Fauziah, P. Y. (2021). Perspektif dan Peran Orangtua dalam Program PJJ Masa Pandemi Covid-19 di PAUD. Jurnal Obsesi : Jurnal Pendidikan Anak Usia Dini, 5(2), 13041312. https:// doi.org/10.31004/obsesi.v5i2.768

Yulianingsih, W., Suhanadji, S., Nugroho, R., \& Mustakim. (2021). Keterlibatan Orangtua dalam Pendampingan Belajar Anak selama Masa Pandemi Covid-19. Jurnal Obsesi: Jurnal Pendidikan Anak Usia Dini, 5(2), 1138-1150. https://doi.org/10.31004/obsesi.v5i2.740 